Terakreditasi: SK No.: 60/E/KPT/2016

Website : http://ejournal.undip.ac.id/index.php/reaktor/

Reaktor, Vol. 17 No. 1, Maret Tahun 2017, Hal. 36-42

\title{
Pengaruh Konsentrasi Doping Nitrogen (N) pada Material Fotokatalis Seng Oksida (ZnO) Terhadap Degradasi Limbah Zat Pewarna Tekstil
}

\author{
Heri Sutanto ${ }^{1,2, *)}$, Eko Hidayanto1,2), Muhammad Irwanto ${ }^{1,2)}$, Agus Romadhon ${ }^{1,2)}$, dan \\ Yoyon Wahyono ${ }^{1,2)}$ \\ ${ }^{1)}$ Departemen Fisika, Fakultas Sains dan Matematika Universitas Diponegoro \\ Jl. Prof. Soedarto, SH, Tembalang, Semarang \\ Telp./Fax. (024)74680822/(024) 74680822 \\ ${ }^{2)}$ Smart Materials Research Center (Smarc), Universitas Diponegoro \\ Jl. Prof. Soedarto, SH, Tembalang, Semarang \\ Telp. $(+62) 85325202360$ \\ *Penulis korespondensi : herisutanto@fisika.undip.ac.id
}

\begin{abstract}
THE EFFECT OF NITROGEN (N) DOPING IN PHOTOCATALYST MATERIAL OF ZINC OXIDE (ZnO) ON DEGRADATION OF WASTE OF TEXTILES DYE. The textile industry produces $50 \%$ of the wasted dye and liquid waste which can cause damage to the river ecosystem. The results of synthesis and characterization of $\mathrm{N}-\mathrm{ZnO}$ photocatalysts and its ability to degrade waste water of batik dye by identifying of the effect of nitrogen $(N)$ doping on $\mathrm{ZnO}$ were reported in this paper. Synthesis of $\mathrm{N}-\mathrm{ZnO}$ material was performed using sol-gel method at room temperature, then the solution was deposited on a glass substrate at $450^{\circ} \mathrm{C}$ with a spray coating method. $\mathrm{N}-\mathrm{ZnO}$ was prepared by $\mathrm{N}$ doping with different percentages of 0, 3, 5, 7 and 9\%, respectively. Degradation of dye waste was performed under UV radiation for 12 hours. The synthesis results show that thin layers have wurtzite polycrystalline structure with dominant orientation field (002). The addition of $N$ doping causes the value of the energy band gap of $\mathrm{ZnO}$ to be smaller. The test results of photocatalysts show that the addition of doping $\mathrm{N}$ on $\mathrm{ZnO}$ does not have a significant influence on the percentage of degradation waste batik dye under UV light. The best ability of $\mathrm{N}-\mathrm{ZnO}$ photocatalytic was obtained in 5\% of $\mathrm{N}$ doping, and the degradation percentage, COD and BOD were $11.83 \%, 6.12 \%$ and $6.40 \%$ respectively.
\end{abstract}

Keywords: degradation; $N$ doped; $\mathrm{ZnO}$ photocatalyst; batik dye waste

Abstrak

Industri tekstil menghasilkan 50\% zat warna yang terbuang dan menjadi limbah dalam bentuk cair yang dapat mengakibatkan rusaknya ekosistem sungai. Pada paper ini dilaporkan hasil sintesis dan karakterisasi fotokatalis $\mathrm{N}$-ZnO serta uji kemampuan fotokatalitiknya dalam mendegradasi limbah cair zat pewarna batik dengan mengidentifikasi pengaruh doping Nitrogen (N) pada ZnO. Sintesis material $\mathrm{N}$-ZnO menggunakan metode sol-gel pada temperatur kamar, kemudian larutan dideposisi di atas substrat kaca pada temperatur $450^{\circ} \mathrm{C}$ dengan metode spray coating. Material $\mathrm{N}-\mathrm{ZnO}$ dibuat dengan persentase doping $N$ yang berbeda yaitu 0, 3, 5, 7, dan 9\%. Degradasi limbah zat warna dilakukan dibawah radiasi sinar UV selama 12 jam. Hasil sintesis menunjukkan bahwa lapisan tipis mempunyai struktur polikristal wurtzite dengan bidang orientasi dominan (002). Penambahan doping $N$ secara umum menyebabkan terjadinya pengecilan nilai celah pita energi ZnO. Hasil uji fotokatalitik 
menunjukkan bahwa penambahan doping $N$ pada $\mathrm{ZnO}$ tidak memberikan pengaruh yang signifikan terhadap persentase degradasi limbah cair pewarna batik dibawah cahaya UV. Diperoleh kemampuan uji fotokatalitik $\mathrm{N}-\mathrm{ZnO}$ terbaik pada doping $\mathrm{N}$ sebesar 5\% dengan nilai \% degradasi sebesar 11,83\%, COD 6,12\% dan BOD 6,40\%.

Kata kunci: degradasi; doping $N$; fotokatalis ZnO; limbah pewarna batik

How to Cite This Article: Sutanto, H., Hidayanto, E., Irwanto, M., Romadhon, A., dan Wahyono, Y., (2017), Pengaruh Konsentrasi Doping Nitrogen (N) pada Material Fotokatalis Seng Oksida (ZnO) Terhadap Degradasi Limbah Zat Pewarna Tekstil, Reaktor, 17(1), 36-42, http://dx.doi.org/10.14710/reaktor.17.1.36-42.

\section{PENDAHULUAN}

Industri merupakan salah satu komponen perekonomian penting dalam suatu negara dan sebagai salah satu parameter kemajuan suatu negara. Salah satu industri yang masih berkembang seiring dengan meningkatnya kebutuhan manusia adalah industri tekstil. Industri tekstil menghasilkan limbah berupa zat warna cair yang mengandung campuran dari bahan organik dan anorganik berbahaya bagi biota air dan bagi kesehatan manusia (Ertugay dan Acar, 2017). Zat warna tekstil secara umum mengandung senyawa azo dan turunannya yang merupakan gugus benzena, dan merupakan senyawa yang sulit didegradasi dan bersifat karsinogen (Christina dkk., 2007). Dalam industri tekstil, penggolongan zat warna dibedakan berdasarkan cara penerapannya pada bahan yaitu zat warna asam, basa, dispersi, reaktif, pigmen, direk (direct), dan lainlain (Manurung dkk., 2004).

Industri tekstil menghasilkan $2 \%$ zat warna yang terbuang dan menjadi limbah dalam bentuk cair (Lalnunhlimi dkk., 2016), sedangkan menurut Windasari (2009) bahwa zat warna yang akan terserap adalah sekitar 50\% dan sisanya akan di daur ulang atau dibuang sebagai limbah yang dialirkan menuju tempat penampungan sementara, selanjutnya akan dibuang ke sungai (Perdana dkk., 2014). Zat warna yang digunakan dalam industri tekstil dapat mengakibatkan rusaknya ekosistem sungai serta dapat mempengaruhi kesehatan manusia yang memanfaatkan sungai tersebut untuk kebutuhan sehari-hari, sehingga perlu dilakukan degradasi limbah sebelum dibuang ke sungai.

Beberapa material fotokatalis yang sering digunakan untuk mendegradasi zat warna adalah $\mathrm{ZnO}$ dan $\mathrm{TiO}_{2}$, hal ini karena material tersebut ramah lingkungan dan mudah didapatkan (Sistesya dan Sutanto, 2013; Diebold, 2003). ZnO adalah material semikonduktor dengan celah pita energi $3,37 \mathrm{eV}$ pada suhu kamar (Zhang dkk., 2010; Pant dkk., 2013; Xu dkk., 2013). ZnO sebagai bahan yang sangat menarik karena sifat unik seperti stabilitas kimia yang tinggi, sifat listrik yang baik, transmitansi cahaya tinggi, dapat melapisi substrat dengan sangat baik dan kuat, bersifat optik dan piezoelektrik serta harganya murah (Ivanova dkk., 2011). ZnO banyak dilaporkan mempunyai efektifitas yang tinggi untuk mendegradasi larutan pewarna (Xue-wen dkk., 2013; Akin dan Mualla, 2013) tetapi belum banyak untuk polutan organik. $\mathrm{ZnO}$ memiliki celah pita energi langsung (direct band gap) sebesar 3,37 eV pada suhu kamar, hal ini menyebabkan $\mathrm{ZnO}$ dapat bekerja pada rentang cahaya UV (Reddy dkk., 2013). Untuk meningkatkan performa fotokatalisis dikembangkan dua metode yaitu yang pertama mengubah sifat fisika seperti morfologi dan ukuran partikel, yang kedua adalah menggunakan pemeka (sensitized) warna, penambahan semikonduktor dengan celah energi sempit, doping logam, non logam $(\mathrm{N}, \mathrm{C}, \mathrm{S})$ dan logam transisi. Peningkatan konsentrasi doping non logam pada $\mathrm{ZnO}$ mengubah tingkat energinya, sehingga dapat meningkatkan sifat fisik maupun sifat optiknya (Chauhan dkk., 2010; Das dkk., 2015; Lu dkk., 2016; Ellmer dkk., 2008). Salah satu material doping atau pengotor yang dapat diberikan pada $\mathrm{ZnO}$ adalah Nitrogen (Lavand dan Yuvraj, 2015).

\section{BAHAN DAN METODE}

Alat yang digunakan pada penelitian ini yaitu gelas beaker, pipet tetes, gelas ukur, sprayer, hot plate magnetic stirrer, penyuntik, kompresor, object glass, aluminium foil, spatula dan ultrasonic bath. Bahanbahan yang digunakan dalam penelitian ini yaitu zinc acetate dehydrate, 2-propanol, monoethanolamine (MEA), urea, methanol, aseton dari Merck Chemical PA, dan akuades.

\section{Prosedur Penelitian}

Zinc acetate dehydrate dilarutkan ke dalam 2propanol $26 \mathrm{ml}$ dan diaduk selama 15 menit menggunakan magnetic stirrer dalam kondisi tertutup pada temperatur ruang. Setelah 15 menit, larutan $\mathrm{ZnO}$ ditetesi larutan MEA dengan perbandingan mol 1:1, kemudian larutan $\mathrm{ZnO}$ kembali diaduk selama 15 menit menggunakan magnetic stirrer dalam kondisi tertutup. Setelah itu, serbuk urea sebagai sumber nitrogen dengan persentase yang telah ditentukan dimasukkan ke dalam larutan $\mathrm{ZnO}$ dan kembali diaduk selama 15 menit.

Larutan prekursor $\mathrm{N}-\mathrm{ZnO}$ yang telah dibuat kemudian dideposisi di atas substrat kaca dengan menggunakan metode spray coating. Substrat kaca dibersihkan terlebih dahulu menggunakan methanol, aseton, dan akuades untuk menghilangkan partikelpartikel pengotor organik yang menempel di permukaan, kemudian dipanaskan menggunakan hotplate pada temperatur $450^{\circ} \mathrm{C}$. Substrat gelas yang telah bersih digunakan untuk deposisi dengan cara menyemprotkan sumber prekursor $\mathrm{N}-\mathrm{ZnO}$ pada jarak $\pm 30 \mathrm{~cm}$ tegak lurus di atas substrat menggunakan sprayer pada tekanan 40 Psi. 
Lapisan tipis $\mathrm{N}-\mathrm{ZnO}$ hasil deposisi digunakan untuk mendegradasi limbah zat warna batik dengan cara memasukkan lapisan tipis $\mathrm{N}-\mathrm{ZnO}$ tersebut ke dalam sampel limbah di bawah sinar UV 10 watt secara bersamaan selama 12 jam pada berbagai variasi persentase doping $\mathrm{N}$.

\section{Metode Karakterisasi}

Setelah lapisan tipis terdeposisi di atas substrat kaca dilakukan uji karakterisasi baik mikrostruktur dan sifat optiknya untuk mengetahui sifat-sifat fisis lapisan yang dihasilkan. Uji karakteristik lapisan tipis $\mathrm{N}-\mathrm{ZnO}$ dengan X-Ray Diffractometer (XRD) untuk mengetahui mikrostruktur sampel. Puncak-puncak yang muncul mengindikasikan bahwa sampel bersifat kristal dan selanjutnya dapat ditentukan ukuran kristalitnya dengan mengunakan PersamaanDebyeScherrer berikut:

$$
D=\frac{k \lambda}{B \cos \theta}
$$

dengan $D$ adalah ukuran bulir kristal, $k$ merupakan konstanta Scherrer bernilai 0.9 untuk $\mathrm{ZnO}, \lambda$ adalah panjang gelombang sinar-X yang digunakan pada analisa yaitu $\mathrm{CuK} \alpha 1(\lambda=1.540600 \AA), B$ adalah Full Width at Half Maximum (FWHM) dan $\theta$ adalah posisi sudut puncak difraksi sampel (dalam radian).

Selain uji mikrostruktur dengan XRD, lapisan tipis $\mathrm{N}-\mathrm{ZnO}$ hasil sintesis juga diuji sifat optiknya dengan alat UV Vis Spektrofotometer. Peralatan UV Vis ini juga dapat digunakan untuk mengetahui persentase degradasi hasil uji kemampuan fotokatalitik sampel. Sifat optik material dianalisis dengan mengukur nilai transmitansinya yang kemudian dapat digunakan untuk menentukan lebar celah energi dari material tersebut dengan menggunakan metode Touc plot, dengan persamaan:

$$
\begin{gathered}
\alpha h v=A\left(h v-E_{g}\right)^{1 / 2} \\
A=\log \left(\frac{100}{T}\right)
\end{gathered}
$$

dengan $\alpha$ adalah koefisien absorpsi, adalah energi foton, $E_{g}$ adalah celah pita energi, $A$ adalah absorptivitas dan $T$ adalah persentase transmitansi sampel.

\section{Analisis Degradasi Sampel Limbah Pewarna Batik}

Sampel limbah zat warna batik yang telah didegradasi selama 12 jam dengan fotokatalis $\mathrm{N}-\mathrm{ZnO}$ diuji nilai absorbansinya dengan UV-Vis Spektrofotometer. Absorbansi yang diperoleh dari masing-masing sampel digunakan untuk menentukan persentase degradasi dengan menggunakan Persamaanberikut:

$$
D_{t}=\frac{\left(A_{o}-A_{t}\right)}{A_{o}} \times 100 \%
$$

dengan $D_{t}$ adalah persentase degradasi sampel pada waktu-t, $A_{t}$ merupakan absorbansi optik sampel pada waktu-t, dan $A_{0}$ merupakan absorbansi optik sampel sebelum didegradasi.

\section{Analisis Parameter Sampel Air}

Analisis kadar Chemical Oxygen Demand (COD) menggunakan standar pengujian SNI 066989.15-2004. Sampel uji dicampur dengan asam sulfat dan kalium dikromat yang telah diketahui normalitasnya dan dipanaskan selama 2 jam di atas hot plate, kemudian didinginkan hingga temperatur kamar dan ditambahkan dengan larutan FAS $0,1 \mathrm{~N}$ hingga berwarna merah kecoklatan. Persamaan yang digunakan dalam menentukan kadar COD adalah:

$$
C O D=\frac{(A-B)(N)(8000)}{V_{O}}
$$

dengan $A$ dan $B$ merupakan volume larutan FAS yang dibutuhkan untuk blanko dan sampel uji, $N$ adalah normalitas larutan Ferro Ammonium Sulfat (FAS), dan $V$ adalah volume sampel uji dalam $\mathrm{ml}$.

Analisis kadar Biologycal Oxygen Demand (BOD) menggunakan standar pengujian SNI 6989.722009. Sampel uji ditambahkan ke dalam larutan pengencer yang telah ditambahkan nutrisi dan bibit mikroba untuk menentukan kadar BOD, kemudian sampel diinkubasi dalam ruang gelap pada suhu $20^{\circ} \mathrm{C}$ selama 5 hari. Nilai BOD dihitung berdasarkan selisih konsentrasi oksigen terlarut 0 (nol) hari dan 5 (lima) hari dengan persamaan:

$$
C O D=\frac{\left(A_{0}-A_{5}\right)\left(\frac{B_{0}-B_{5}}{V_{B}}\right) V_{S}}{P}
$$

dengan $A_{0}$ dan $A_{5}$ merupakan kadar oksigen terlarut dalam sampel uji pada hari ke-0 dan hari ke-5, $B_{0}$ dan $B_{5}$ merupakan kadar oksigen terlarut dalam sampel uji pada hari ke-0 dan hari ke-5, $V_{B}$ dan $V_{S}$ merupakan volume suspense mikroba $(\mathrm{ml})$ dalam botol blanko dan dalam botol sampel uji, serta $P$ merupakan perbandingan volume sampel uji $\left(\mathrm{V}_{1}\right)$ per volume total $\left(\mathrm{V}_{2}\right)$.

\section{HASIL DAN PEMBAHASAN}

Lapisan tipis $\mathrm{ZnO}$ dan $\mathrm{N}-\mathrm{ZnO}$ telah berhasil disintesis menggunakan metode sol-gel teknik spray coating pada temperatur $450^{\circ} \mathrm{C}$ dan menghasilkan lapisan transparan berwarna pelangi seperti ditunjukkan Gambar 1.

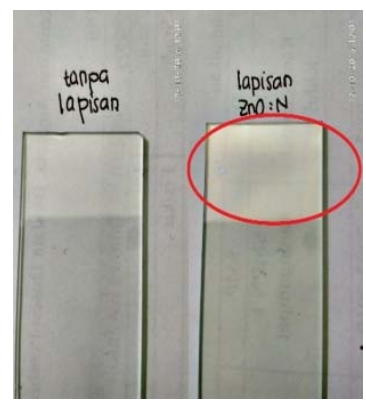

(a)

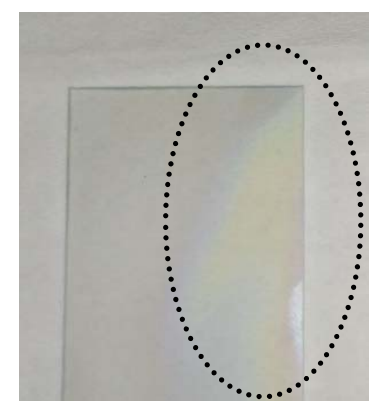

(b)
Gambar 1. (a) Kaca tanpa lapisan tipis dan kaca dengan lapisan tipis $\mathrm{N}-\mathrm{ZnO}$; (b) Lapisan pelangi pada kaca yang dilapisi lapisan tipis $\mathrm{N}-\mathrm{ZnO}$ 
Gambar 1(a) menunjukkan perbandingan antara kaca substrat tanpa lapisan tipis (kiri) dengan kaca substrat dengan lapisan tipis $\mathrm{N}-\mathrm{ZnO}$ (kanan). Kaca substrat dengan lapisan memiliki warna keruh dan jika diamati secara langsung akan terlihat pelangi yang melekat di atasnya seperti yang ditunjukkan pada Gambar 1(b) pada lingkaran hitam. Perbedaan hasil ini dikarenakan adanya kisi-kisi kristal dengan ukuran sangat kecil di atas kaca menyebabkan terjadinya dispersi cahaya polikromatik membentuk spektrum warna pelangi yang monokromatik (Halliday dkk., 2011). Hasil lain dari kualitas lapisan yang terbentuk tidak mudah luntur dan kuat yang menandakan bahwa lapisan kristal telah terdeposisi dengan baik di atas substrat kaca, dikarenakan temperatur deposisi yang tinggi menyebabkan partikel-partikel material melekat dengan kuat pada substratnya.

\section{Karakterisasai Mikrostruktur}

Mikrostuktur lapisan tipis fotokatalis $\mathrm{N}-\mathrm{ZnO}$ dianalisis menggunakan XRD untuk mengetahui struktur kristal dari lapisan hasil sintesis. Hasil uji XRD seperti ditunjukkan Gambar 2.

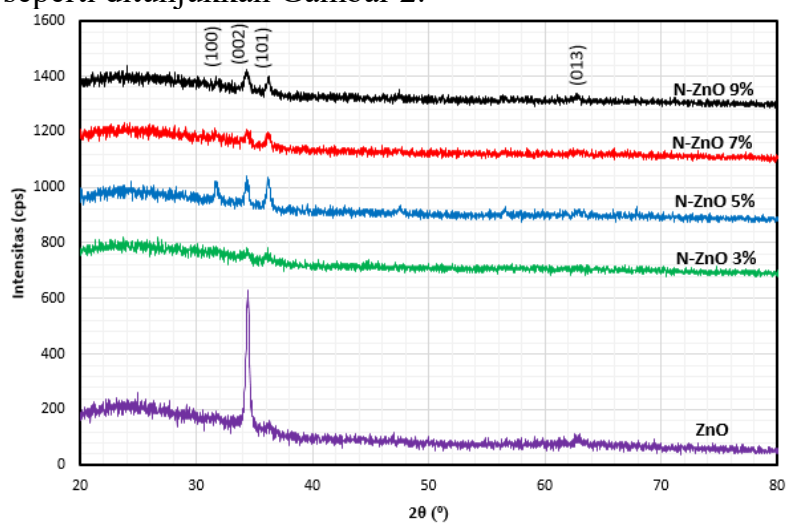

Gambar 2. Pola spektrum XRD ZnO dan N-ZnO

Gambar 2 menunjukkan perbandingan struktur kristal material $\mathrm{ZnO}$ dan $\mathrm{N}-\mathrm{ZnO}$ dengan berbagai variasi doping $\mathrm{N}$. $\mathrm{ZnO}$ tanpa doping memiliki 3 puncak difraksi yaitu pada bidang (002), (101) dan (013) sesuai database COD JCPDS \#96-901-1663. Lapisan tipis $\mathrm{ZnO}$ tanpa doping mempunyai orientasi kristal tertinggi pada bidang (002). Penambahan doping $\mathrm{N}$ pada matrik $\mathrm{ZnO}$ menyebabkan penurunan kualitas kristal lapisan tipis $\mathrm{N}-\mathrm{ZnO}$ hasil deposisi diamati dari penurunan puncak difraksi pada bidang utama (002) yang mengindikasikan hadirnya $\mathrm{N}$ tersebut menyebabkan terjadinya cacat kristal pada struktur utama ZnO. Data uji XRD pada sampel dengan doping $\mathrm{N}$ sebesar 5\% menunjukkan kualitas mikrostruktur khususnya fase kristal yang lebih baik daripada lapisan $\mathrm{N}-\mathrm{ZnO}$ dengan doping N 3, 7 dan 9\% ditunjukkan dari intensitas yang tinggi pada bidang difraksi (002). Puncak intensitas difraksi menunjukkan bidang kristal yang terbentuk, yaitu (110), (002), (101), (012), dan (013) berdasarkan database COD \#96-901-1663 yang merupakan basis data struktur kristal material $\mathrm{ZnO}$ dengan struktur heksagonal menggunakan radiasi $\mathrm{CuK} \alpha 1$. Banyaknya bidang kristal yang terbentuk menandakan bahwa material $\mathrm{N}-\mathrm{ZnO}$ yang terbentuk memiliki fasa polikristalin. Hasil perhitungan ukuran kristalit dengan menggunakan persamaan (1) pada $\mathrm{Z}-\mathrm{ZnO} 5 \%$ untuk semua bidang difraksi ditampilkan di Tabel 1 dan $\mathrm{N}$ $\mathrm{ZnO}$ pada berbagai variasi doping $\mathrm{N}$ pada puncak difraksi (002) ditampilkan di Tabel 2.

Tabel 1 memperlihatkan bahwa ukuran bulir kristal $\mathrm{N}-\mathrm{ZnO} 5 \%$ yang terbentuk berada pada rentang $11 \mathrm{~nm}$ hingga $23 \mathrm{~nm}$, dengan ukuran rata-rata 19,642 $\mathrm{nm}$. Hal ini menunjukkan bahwa material $\mathrm{N}-\mathrm{ZnO}$ yang telah terbentuk merupakan nanomaterial $\mathrm{N}-\mathrm{ZnO}$ mirip seperti hasil penelitian yang telah dilakukan Lovestam dkk. (2010).

Tabel 1. Ukuran kristalit N-ZnO 5\% pada semua puncak difraksi XRD

\begin{tabular}{cc}
\hline $2 \theta$ & $\mathrm{D}(\mathrm{nm})$ \\
\hline 31,38 & 23,095 \\
34,20 & 21,719 \\
36,04 & 21,864 \\
62,74 & 11,892 \\
\hline
\end{tabular}

Tabel 2. Ukuran kristalit N-ZnO bidang (002) pada berbagai persentase doping $\mathrm{N}$

\begin{tabular}{cccc}
\hline$\%$ & $2 \theta$ & FWHM $\left.^{\circ}\right)$ & D $(\mathrm{nm})$ \\
\hline 3 & 34,36 & 0,4626 & 17,975 \\
5 & 34,20 & 0,3827 & 21,719 \\
7 & 34,38 & 0,4461 & 18,641 \\
9 & 34,36 & 0,4020 & 20,685 \\
\hline
\end{tabular}

Tabel 2 menunjukkan bahwa ukuran bulir kristal pada $\mathrm{N}-\mathrm{ZnO}$ dengan persentase yang berbeda memiliki nilai yang berbeda, sehingga hal ini menunjukkan bahwa persentase penambahan doping $\mathrm{N}$ akan mempengaruhi ukuran kristal yang terbentuk. Tabel 2 menunjukkan secara umum ukuran kristal pada bidang (002) semakin besar ketika persentase doping $\mathrm{N}$ meningkat, kecuali pada persentase doping 5\% yang memiliki ukuran kristal paling besar. Hasil uji XRD pada bidang difraksi dominan (002) juga menunjukkan nilai FWHM dari sampel $\mathrm{N}-\mathrm{ZnO} 5 \%$ paling kecil sebesar $0,3827^{\circ}$ yang menyatakan bahwa kualitas kristal terbaik dihasilkan pada sampel tersebut.

\section{Karakterisasi Optik N-ZnO}

Sifat optik material fotokatalis $\mathrm{N}-\mathrm{ZnO}$ dianalisis menggunakan spektrofotometer UV-Vis, yaitu persentase transmitansi dari material $\mathrm{N}-\mathrm{ZnO}$ ketika dikenakan spectrum panjang gelombang cahaya tampak hingga ultra violet. Gambar 3 menunjukkan hasil uji perbandingan persentase transmitansi dari masing-masing material $\mathrm{ZnO}$ dan $\mathrm{N}-\mathrm{ZnO}$ dan secara umum material $\mathrm{N}-\mathrm{ZnO}$ memiliki nilai transmitansi yang lebih tinggi dibandingkan dengan material $\mathrm{ZnO}$ tanpa doping. Hal ini menunjukkan bahwa penambahan $\mathrm{N}$ (Nitrogen) sebagai dopan mengakibatkan terjadinya perubahan sifat optik pada material $\mathrm{ZnO}$.

Selain itu, Gambar 3 menunjukkan bahwa material $\mathrm{ZnO}$ yang diberi doping $\mathrm{N}$ memiliki nilai transmitansi dengan pola lebih terjal daripada material 
$\mathrm{ZnO}$ tanpa doping dan dapat dilihat pada rentang panjang gelombang $300 \mathrm{~nm}$ hingga $400 \mathrm{~nm}$. Hal ini menunjukkan bahwa material $\mathrm{N}-\mathrm{ZnO}$ memiliki sifat transparan yang lebih baik daripada material $\mathrm{ZnO}$ tanpa doping. Jika ditinjau lebih lanjut dari grafik tersebut, dapat dilihat bahwa material $\mathrm{N}-\mathrm{ZnO} 5 \%$ memiliki nilai transmitansi yang rendah pada rentang panjang gelombang tersebut yang menyatakan bahwa serapan optiknya tinggi jika dibandingkan dengan $\mathrm{N}-\mathrm{ZnO}$ lainnya. Serapan optik (absorbansi) yang tinggi menyatakan energi yang bersumber dari luar digunakan untuk proses terjadinya pasangan elektron-hole yang dimanfaatkan dalam proses reduksi dan oksidasi pada degradasi polutan.

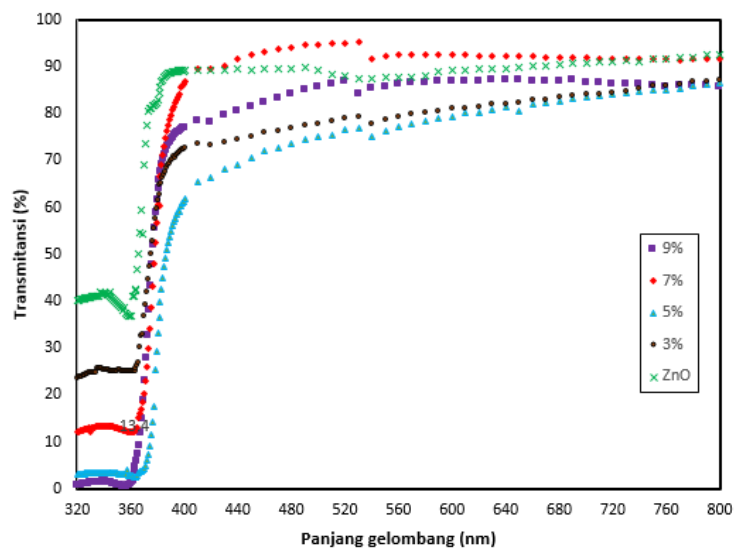

Gambar 3. Transmitansi ZnO dan N-ZnO dengan persentase yang bervariasi

Grafik celah energi masing-masing material $\mathrm{ZnO}$ dan $\mathrm{N}-\mathrm{ZnO}$ untuk yang diperoleh menggunakan metode Touc plot ditunjukkan pada Gambar 4. Pada Gambar 4 terlihat bahwa material $\mathrm{N}-\mathrm{ZnO}$ memiliki lebar celah energi lebih kecil daripada $\mathrm{ZnO}$ tanpa doping. Lebar celah energi $\mathrm{ZnO}$ yang diperoleh pada penelitian ini adalah $3,28 \mathrm{eV}$, sedangkan menurut referensi lebar celah energi $\mathrm{ZnO}$ adalah $3,37 \mathrm{eV}$ pada suhu kamar dan 3,44 eV pada suhu rendah. Perbedaan nilai celah energi dapat disebabkan oleh adanya pengotor dalam material $\mathrm{ZnO}$ sehingga lebar celah energinya bergeser. Lebar celah energi yang diperoleh pada material $\mathrm{N}-\mathrm{ZnO}$ lebih kecil daripada $\mathrm{ZnO}$ tanpa doping, hal ini sesuai dengan hasil penelitian lain bahwa unsur $\mathrm{N}$ dalam $\mathrm{ZnO}$ menyebabkan lebar celah energi $\mathrm{ZnO}$ menjadi lebih kecil (Ellmer dkk., 2008).

Secara umum material $\mathrm{N}-\mathrm{ZnO}$ yang diperoleh memiliki lebar celah energi di bawah $3 \mathrm{eV}$, menunjukkan bahwa material $\mathrm{N}-\mathrm{ZnO}$ dapat menyerap panjang gelombang hingga lebih dari 414,4 nm yang merupakan spektrum warna ungu dalam cahaya tampak (Halliday dkk., 2011). Lebar celah energi paling rendah pada material $\mathrm{N}-\mathrm{ZnO}$ yang diperoleh adalah $2,9378 \mathrm{eV}$ yaitu pada persentase doping $\mathrm{N}$ sebanyak 5\%. Sedangkan lebar celah energi $\mathrm{N}-\mathrm{ZnO}$ dengan persentase 7 dan $9 \%$ cenderung meningkat dengan perubahan yang cukup kecil yaitu kurang dari $0,03 \mathrm{eV}$. Penurunan celah pita energi ini mempunyai kontribusi yang sangat baik dalam proses degradasi Karena sumber spectrum cahaya menjadi lebih luas/lebar yaitu dari cahaya tampak hingga ultra violet sehingga berimplikasi pada semakin banyaknya radikal hidroksil maupun superoksida yang dihasilkan selama proses fotokatalitik lapisan $\mathrm{N}-\mathrm{ZnO}$.

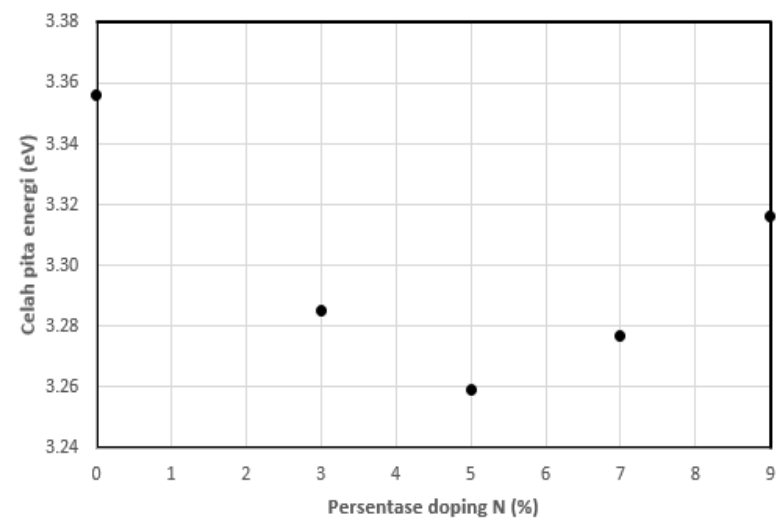

Gambar 4. Grafik lebar celah energi pada sampel $\mathrm{ZnO}$ dan $\mathrm{N}-\mathrm{ZnO}$ terhadap persentase doping yang digunakan

\section{Degradasi Zat Warna oleh Fotokatalis N-ZnO}

Limbah zat warna didegradasi menggunakan material fotokatalis $\mathrm{ZnO}$ dan $\mathrm{N}-\mathrm{ZnO} 3,5$, 7, dan 9\% dibawah radiasi sinar UV 10 watt selama 12 jam. Gambar 5 memperlihatkan bahwa material $\mathrm{N}-\mathrm{ZnO}$ lebih baik dalam mendegradasi limbah zat warna batik dibandingkan dengan $\mathrm{ZnO}$ tanpa doping. Persentase doping sebanding dengan hasil degradasi yang diperoleh selama 12 jam, kecuali pada penambahan doping 5\% yang mendegradasi limbah pewarna paling baik. Persentase limbah yang terdegradasi oleh material $\mathrm{N}-\mathrm{ZnO} 5 \%$ tertinggi sebesar $11.83 \%$ dengan laju degradasi sebesar $0.99 \%$ per jam. Hasil uji degradasi ini diperkuat dari hasil uji mikrostruktur lapisan tipis $\mathrm{N}$ ZnO 5\% yang mempunyai kualitas kristal terbaik dan hasil uji sifat optik yang menunjukkan nilai \%transmitasi paling rendah dan nilai lebar celah nerginya terkecil yang mengakibatkan semakin banyaknya radikal hidroksil dan superoksida yang terbentuk saat lapisan terkena paparan cahaya tampak dan ultraviolet saat uji degradasi berlangsung menyebabkan semakin cepat proses pemutusan ikatan kimia sumber polutan pewarna dan menyebabkan sampel limbah pewarna menjadi lebih jernih. Polutan pewarna jenis benzene termasuk gugus yang sulit dedegradasi (Christina dkk., 2007), dan hal ini seperti penelitian yang dilakukan penulis yaitu hasil uji kemampuan fotokatalitik lapisan tipis $\mathrm{N}-\mathrm{ZnO}$ terbaik pada sampel dengan doping $\mathrm{N}$ sebesar 5\% yang masih dibawah $12 \%$.

Aktivitas fotokatalitik $\mathrm{N}-\mathrm{ZnO}$ lebih baik dibandingkan dengan aktivitas $\mathrm{ZnO}$ tanpa doping dibawah sinar UV yang ditunjukkan dengan meningkatnya limbah yang terdegradasi oleh material $\mathrm{N}-\mathrm{ZnO}$ dibandingkan oleh $\mathrm{ZnO}$, hal ini dikarenakan unsur $\mathrm{N}$ merupakan pendonor elektron sehingga jumlah 
elektron bebas yang dimiliki oleh $\mathrm{N}-\mathrm{ZnO}$ akan lebih banyak dibandingkan dengan $\mathrm{ZnO}$ tanpa doping. Berdasarkan pada proses fotokatalitik material semikonduktor dalam air, pasangan elektron dan hole terbentuk akibat adanya penyinaran material oleh sinar UV. Hole yang terbentuk bereaksi dengan air di permukaan material membentuk $\mathrm{OH}^{*}$, sedangkan elektron akan mereduksi $\mathrm{O}_{2}$ menjadi $\mathrm{O}_{2}^{-}$. Dengan adanya tambahan elektron bebas yang disumbangkan oleh $\mathrm{N}$ maka reduksi $\mathrm{O}_{2}$ menjadi $\mathrm{O}_{2}^{-}$lebih banyak, sehingga proses pemutusan ikatan senyawa kimia oleh $\mathrm{O}_{2}^{-}$menjadi lebih banyak.

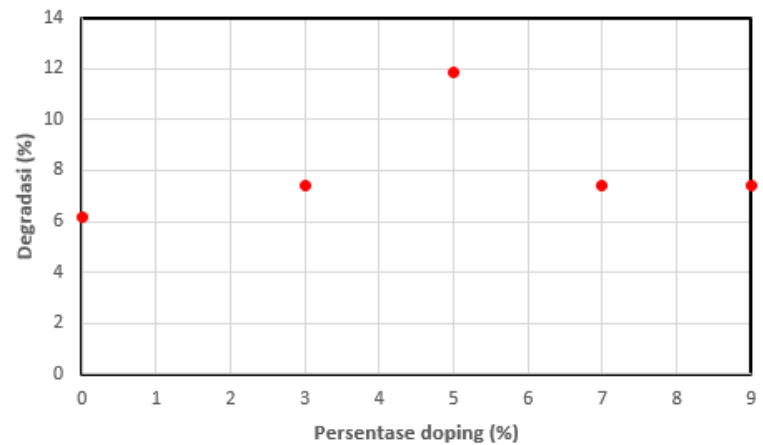

Gambar 5. Persentase degradasi limbah selama 12 jam menggunakan $\mathrm{ZnO}$ dan $\mathrm{N}-\mathrm{ZnO}$ dibawah sinar UV

Gambar 5 juga menunjukkan bahwa penambahan $\mathrm{N}$ pada material fotokatalis $\mathrm{ZnO}$ tidak mempengaruhi proses degradasi secara signifikan terhadap sampel limbah zat warna di bawah radiasi cahaya UV, hal ini terlihat pada perbedaan nilai yang terdegradasi antara material $\mathrm{N}-\mathrm{ZnO}$ dengan $\mathrm{ZnO}$ tanpa doping hanya $1-5 \%$. Sedangkan jika dilihat dari lebar celah pita energinya, material N-ZnO akan lebih efektif bekerja dibawah panjang gelombang sinar tampak jika dibandingkan dengan material $\mathrm{ZnO}$ yang lebih efektif bekerja dibawah panjang gelombang UV.

\section{Kandungan Kimia dan Mikroorganik Limbah}

Pengujian kandungan kimia dengan uji COD dan kandungan mikroorganik dengan uji BOD dilakukan pada sampel dengan kemampuan degradasi pewarna tertinggi yaitu pada sampel $\mathrm{N}-\mathrm{ZnO} 5 \%$. Hasil uji COD dan BOD ditampilkan pada Tabel 3.

Tabel 3. Kualitas air limbah sebelum dan setelah didegradasi menggunakan $\mathrm{N}-\mathrm{ZnO} 5 \%$ selama 12 jam

\begin{tabular}{ccc}
\hline Sampel & COD $(\mathrm{ppm})$ & BOD $(\mathrm{ppm})$ \\
\hline Sebelum degradasi & 109,34 & 33,89 \\
Setelah degradasi & 102,65 & 31,72 \\
\hline
\end{tabular}

Hasil pengujian (Tabel 3) memperlihatkan bahwa kadar COD dan BOD yang mengindikasikan adanya polusi organik dari sampel limbah menurun setelah didegradasi menggunakan material $\mathrm{N}-\mathrm{ZnO} 5 \%$. Hasil ini menunjukkan bahwa material $\mathrm{N}-\mathrm{ZnO} 5 \%$ mampu mendegradasi senyawa organik dan mikroorganisme yang terdapat di dalam limbah. Penurunan kadar COD 6,12\% dan BOD 6,40\% masih sangat rendah menandakan bahwa material $\mathrm{N}-\mathrm{ZnO}$ belum mampu mendegradasi parameter tersebut secara maksimal, namun dari hasil uji ini menunjukkan juga bahwa material $\mathrm{ZnO}$ memiliki sifat sebagai antibakteri seperti penelitian yang dilakukan oleh Santhoshkumar dkk. (2016).

\section{KESIMPULAN}

Sintesis lapisan tipis $\mathrm{ZnO}$ dan $\mathrm{N}-\mathrm{ZnO}$ telah berhasil dilakukan di atas substrat kaca dengan struktur polikristalin dengan puncak difraksi dominan pada bidang (002). Penambahan doping $N$ secara umum memperbesar ukuran bulir kristal dan mengurangi lebar celah energinya hingga 2,9378 eV dibandingkan dengan $\mathrm{ZnO}$ tanpa doping. Lapisan $\mathrm{ZnO}$ yang diberi doping $\mathrm{N}$ memiliki nilai transmitansi dengan pola lebih terjal daripada material $\mathrm{ZnO}$ tanpa doping pada rentang panjang gelombang $300 \mathrm{~nm}$ hingga $400 \mathrm{~nm}$. Material fotokatalis $\mathrm{N}-\mathrm{ZnO}$ dengan persentase doping sebanyak $5 \%$ mampu mendegradasi limbah zat pewarna batik paling baik dibandingkan dengan $\mathrm{ZnO}$ dan $\mathrm{N}-\mathrm{ZnO}$ pada persentase doping lainnya. Hasil uji fotokatalitik N$\mathrm{ZnO}$ doping $\mathrm{N}$ sebesar 5\% terhadap limbah pewarna batik diperoleh persentase degradasi tertinggi sebesar $11,83 \%$ dari kondisi awal selama 12 jam, COD sebesar $6,12 \%$ dan BOD sebesar $6,40 \%$.

\section{UCAPAN TERIMA KASIH}

Terima kasih disampaikan kepada Pemerintah Republik Indonesia melalui Kementerian Riset, Teknologi dan Pendidikan Tinggi atas pendanaan penelitian ini melalui skim Hibah Fundamental tahun anggaran 2017.

\section{DAFTAR PUSTAKA}

Akin, M.B. and Mualla, O., (2013), Photodegradation of Methylene Blue with Sphere-like ZnO Particles Prepared Via Aqueous Solution, Ceramics International, 39, pp. 9759-9762.

Chauhan, R., Ashavani, K., and Ram, P.C., (2010), Synthesis and Characterisation of Silver Doped $\mathrm{ZnO}$ Nanoparticles, Journal of Solar Research Library, 2, pp. 378-385.

Christina, P.M., Mu'nisatun S., Saptaaji, R., dan Djoko, M., (2007), Studi Pendahuluan Mengenai Degradasi Zat Warna Azo (Metil Orange) dalam Pelarut Air Menggunakan Mesin Berkas Elektron $350 \mathrm{keV} / 10$ mA, Jurnal Fisika Nuklir (JFN), 1(1), pp. 1978-8738.

Das, S., Patra, S., Kar, J.P., Roy, A., Ray, A., and Myoung, J.M., (2015), Origin of p-type Conductivity for N-doped $\mathrm{ZnO}$ Nanostructure Synthesized by MOCVD Method, Materials Letters, 161, pp. 701-704.

Diebold, U., (2003), The Surface Science of Titanium Dioxide, Surface Science Report, 48, pp. 53-229.

Ellmer, K., Andreas, K., and Bernd, R., (2008), Transparent Conductive Zinc Oxide: Basics and 
Applications in Thin Film Solar Cell, Verlag Berlin Heidelberg: Springer.

Ertugay, N. and Acar, F.N., (2017), Removal of COD and Color from Direct Blue 71 Azo Dye Wastewater by Fenton's Oxidation: Kinetic Study, Arabian Journal of Chemistry, 10(1), pp. S1158-S1163.

Halliday, D., Robert, R., and Jearl, W., (2011), Fundamental of Physics ( $9^{\text {th }}$ Edition), Jefferson: John Wiley \& Sons, Inc.

Heryanti A., Oktavianto, A.T., Annisa, E.N., Yuliana, E., Zaidah, R., Amaliyah, T., Latifa, W., dan Lamsari, Y., (2014), Penentuan Kadar COD pada Air Limbah Industri Tekstil di Desa Beng Gianyar dengan Metode Titrasi Titrimetri (Refluks Tertutup). Laboratorium Kima STIKes Wira Medika Bali.

Ivanova, T., Harizanova, A., Koutzarova, T., and Vertruyen, B., (2011), Preparation and Characterization of $\mathrm{ZnO} / \mathrm{TiO}_{2}$ Films Obtained by Solgel Method, Journal of Non-Crystalline Solids, 375, pp. 2840-2845.

Lalnunhlimi, S. and Krishnaswamy, V., (2016), Decolorization of Azo Dyes (Direct Blue 151 and Direct Red 31) by Moderately Alkaliphilic Bacterial Consortium, Brazilian Journal of Microbiology, 47, pp. 39-46.

Lavand, A.B. and Yuvraj, S.M., (2015), Synthesis, Characterization and Visible Light Photocatalytic Activity of Nitrogen-doped Zinc Oxide Nanospheres, Journal of Asian Ceramic Societies, 3, pp. 305-310.

Lu, H., Zhou, P., Liu, H., Zhang, L., Yu, Y., Li, Y., and Wang, Z., (2016), Effects of Nitrogen and Oxygen Partial Pressure on The Structural and Optical Properties of ZnO:N Thin Films Prepared by Magnetron Sputtering, Materials Letters, 165, pp. 123126.

Manurung, R., Rosdanelli, H., and Irvan. (2004), Perombakan Zat Warna Azo Reaktif Secara AnaerobAerob, Sumatera Utara: Universitas Sumatera Utara.
Pant, H.R, Bishweshwar, P, Ram, K.S., Altangerel, A., Han, J.K., Chan, H.P., Leonard, D.T., and Cheol, S.K. (2013), Antibacterial and Photocatalytic Properties of $\mathrm{Ag} / \mathrm{TiO}_{2} / \mathrm{ZnO}$ Nano-flowers Prepared by Facile Onepot Hydrothermal Process, Ceramics International, 39, pp. 1503-1510.

Reddy, S.B., Venkatramana, R., Koteeswara, R., and Pramoda, K., (2013), Synthesis, Structural, Optikal Properties and Antibacterial Activity of Co-doped (Ag, Co) ZnO Nanoparticles, Research Journal of Material Sciences, 1, pp. 11-20.

Santhoshkumar, A., Helen, P.K., and Suresh R., (2016), Spectroscopic Characterisation and Antibacterial Activity of ZnO Nanosheets. Karbala International Journal of Modern Science, 2(3), pp. 196-202.

Sistesya, D. dan Sutanto, H., (2013), Sifat Optis Lapisan ZnO:Ag yang Dideposisi di atas Substrat Kaca Menggunakan Metode Chemical Deposition (CSD) dan Aplikasinya pada Degradasi Zat Warna Methylene Blue, Youngster Physics Journal, 1(4), pp. 71-80.

Windasari, R., (2009), Adsorpsi Zat Warna Tekstil Direct Blue 86 oleh Kulit Kacang Tanah, Skripsi, Jurusan Kimia, FMIPA, Universitas Negeri Semarang, Semarang.

Xu, L., Gaige, Z., Hongyan, W., Junfeng, W., Fang, G., Jing, S., Fenglin, X., and Zhanhui, L. (2013), Strong Ultraviolet and Violet Emissions from $\mathrm{ZnO} / \mathrm{TiO}_{2}$ Multilayer Thin Films, Optical Materials, 35, pp. 1582-1586.

Xue-wen, W., Zhou, L., and Li, F. (2013), ZnO Disks Loaded with Reduced Graphene Oxide for The Photodegradation of Methylene Blue, New Carbon Materials, 28(6), pp. 408-413.

Zhang, W., Jianguo, Z., Zhenzhong, L., Zhaojun, L., and Zhuxi, F., (2010), Influence of Growth Temperature of $\mathrm{TiO}_{2}$ Buffer on Structure and PL Properties of ZnO Films, Applied Surface Science, 256, pp. 4423-4425. 